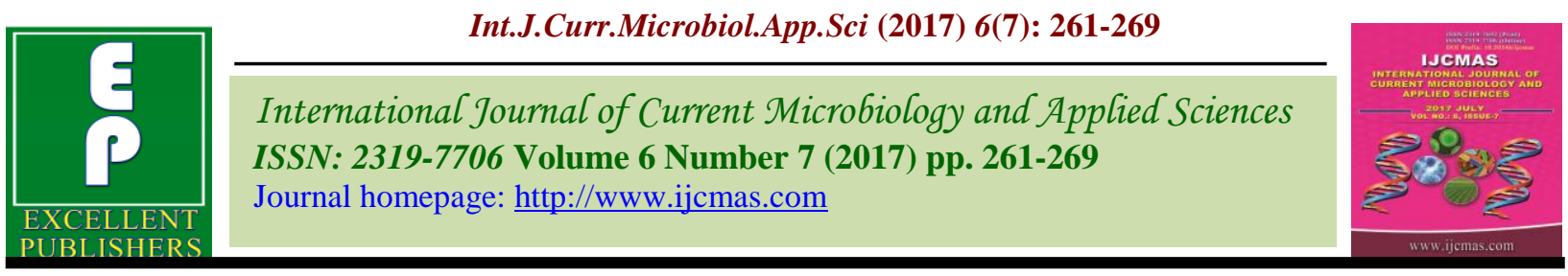

Original Research Article

https://doi.org/10.20546/ijcmas.2017.607.031

\title{
Effect of Deficit Irrigation Scheduling on Yield and Quality of Kinnow Mandarin Fruits
}

\author{
Disket Dolker $^{1 *}$, Parshant Bakshi ${ }^{1}$, Stanzin Dorjey ${ }^{2}$, Preeti Choudhary ${ }^{1}$, \\ Kiran Kour ${ }^{1}$ and Mahender Singh ${ }^{3}$ \\ ${ }^{1}$ Division of Fruit Science, Sher-e-Kashmir University of Agricultural Sciences and Technology \\ of Jammu, Main Campus, Chatha-180009, Jammu, India \\ ${ }^{2}$ Division of Plant Pathology, Sher-e-Kashmir University of Agricultural Sciences and \\ Technology of Kashmir, Wadura Sopore, 193201, Kashmir, India \\ ${ }^{3}$ Agrometrology Centre, SKUAST-Jammu, Chatha-180009, Jammu, India \\ *Corresponding author
}

\section{A B S T R A C T}

\begin{tabular}{l} 
Key w or d s \\
Irrigation, \\
Mandarin fruits, \\
Yield and quality. \\
\hline Article Info \\
\hline Accepted: \\
04 June 2017 \\
Available Online: \\
10 July 2017
\end{tabular}

Scarcity of irrigation water in critical growth stages of the crop is one of the major causes of low productivity and decline of citrus orchards. Regulated deficit irrigation (RDI) is a recently proposed water saving technique in irrigated agriculture. The present study was planned with a hypothesis that the optimal RDI scheduling at early fruit growth period (EFGP), which coincides with summer months could save substantial amount of water, without significantly affecting the yield of 'Kinnow' mandarin plants. The greater plant growth was recorded with fully-irrigated plants $\left(\mathrm{RDI}_{100-100-100}\right.$.) while, maximum fruit yield with better quality was recorded under plant treated with RDI at 100\% ETc at early and 50\% ETc in final fruit growth period $\left(\mathrm{T}_{8}\right)$. Conversely higher acidity and lower total soluble solid with the fruits in $\mathrm{RDI}_{0-100-0}$ treatment compared to other treatments.

\section{Introduction}

Water availability becomes a major constraint to crop production in almost all regions of the world. In recent years, regulated deficit irrigation (RDI) has emerged as one of the potential tools to be used for sustainable crop production in water scarce regions. Reducing water supply to optimal level of crop water requirement in certain growth stages of the crop improves water use efficiency and quality of produces, without affecting the yield significantly (Panigrahi et al., 2014). Citrus, an evergreen and high water requiring perennial fruit crop, is mainly grown in tropical and sub-tropical regions of the world. Irrigation water is a key input to successful cultivation of citrus (Singh and Srivastava, 2004). Drip irrigation (DI) is one of the potential water saving irrigation methods in citrus (Panigrahi et al., 2012a). In recent years, several research contributions have documented the advantages of DI in citrus in water scarce regions. Abu-Awwad (2001) reported that irrigation at $100 \%$ evaporation produced the highest fruit yield. Kallsen and Sanden (2011) stated that the intensity of water stress decreased the fruit yield by 
number and weight and also decreased the percentage of large fruit. In another experiment, the effect of drip irrigation regimes and basin irrigation on agronomical and physiological performance of Nagpur mandarin was investigated. Panigrahi et al., (2012) revealed that highest fruit yield was recorded in DI at $80 \%$ Ecp $\left(34.78 \mathrm{~kg} \mathrm{plant}^{-1}\right)$, followed by DI at $100 \%$ Ecp $(32.91 \mathrm{~kg}$ plant $^{-1}$ ). Similarly, Panigrahi et al., (2014) reported that the total fruit yield of 'Kinnow' mandarin increased with the increase in irrigation regime from no irrigation to full irrigation (FI). In another investigation, Shirgure et al., (2016) reported that the highest fruit yield of Nagpur mandarin was recorded in the drip irrigation scheduled with $30 \%$ evaporation replenishment in stage-VI and $80 \%$ evaporation replenishment in stage I-V (17.25 t/ha and $21.48 \mathrm{t} / \mathrm{ha}$, respectively). Overall, the studies indicate that the level and time of water stress along with its duration are the main factors responsible for success of DI in citrus. Moreover, orchard and crop characteristics such as soil, climate, and cultivar also play a role in success of RDI (Panigrahi and Srivastava, 2011).

'Kinnow' mandarin, a first generated hybrid of King Orange ( $\delta^{\lambda}$ ) and Willow Leaf $(+$ ) , is a leading and commercially important citrus cultivar grown in arid and semiarid environments of northern India, where more than $90 \%$ of annual rainfall $(600 \mathrm{~mm})$ is concentrated in 3-4 months (June-October) of a year. In this region, to improve the productivity of citrus orchards irrigation is practiced during January-June and OctoberDecember and ground wells water or canal water is the common source of irrigation for the crop. However, over the last few years, the shortage of irrigation water caused by over exploitation of ground water has become a major threat to citrus production. On the other hand, the area under Kinnow production has been exponentially increasing due to the cultivar suitability and its higher production economics return compared with others (Bhat et al., 2011). Farmers are more concerned with the sustained production of 'Kinnow' mandarin using less water, which could be achieved through adaptation of RDI technique using drip irrigation for Kinnow mandarin. The earlier study by Hasan and Sirohi (2006) on Kinnow mandarin indicated that the crop is most sensitive to water stress at flowering and fruit set stage which takes place during month of March in northern India. The water scarcity caused by low water level in the wells in summer months (March-June) has forced the orchard growers to opt for RDI during this period. In absence of the information on the responses of mandarin cultivars of citrus to water stress in summer months, which coincides with EFGP, is very limited worldwide. Further, the yield prediction under differential water stress condition is also limited in fruit crops. Since, it has been recognized that the tree itself is the best indicator of water stress and yield (Goldhamer et al., 2003). A new methodology for forecasting yield using plant-based measurements in any growth stage of citrus could also benefit growers. The present experiment was conducted to study the effects of RDI on growth, yield and quality Kinnow mandarin under Jammu sub-tropics.

\section{Materials and Methods}

The field experiment was conducted on eight year old, uniformly growing and bearing habit 'Kinnow' mandarin plants at Research Farm Chatha, Division of Fruit Science, Faculty of Agriculture, Sher-e-Kashmir University of Agricultural Sciences and TechnologyJammu, India. The climate of the experimental orchard is situated in the subtropical zone at latitude of $32^{\circ} 39^{\prime}$ North and longitude of $74^{\circ} 58^{\prime}$ East with hot dry summers and cold winters with mean annual rainfall of about $1110 \mathrm{~mm}$, out of which most 
of the rains are received during June to September and rest in winter. Soil of the experimental site varies from sandy-loam in texture and neutral in reaction. The field capacity and permanent wilting point of the soil varied from 20 to $23 \%$ and 6.3 to $6.9 \%$, respectively, on a volume basis. The study consist of regulated deficit irrigation (RDI) treatments where irrigation was scheduled at different deficit levels (no irrigation and 50\% ETc) in the early fruit growth period (EFGP) and final fruit growth period (FFGP) singly and in combination, and compared with full irrigation $(100 \%$ ETc) in kinnow mandarin. The kinnow fruit has three distinct phases of growth: (i) the early fruit growth period (EFGP), from fruit setting to 60 days after fruit set; (ii) mid fruit growth period (MFGP, from 60 days after fruit set to 180 days after fruit set); and (iii) final fruit growth period (FFGP, from 180 days after fruit set to 225 days after fruit set), as suggested by Dhillon (1986). Irrigation season was from midJanuary to June and from mid-October to December during both the experimental years. Water supply was stopped during monsoon season (June to September) due to adequate rainfall fulfilling the crop water need during this period (Figure 1). The treatment details are presented in table 1.

The volume level of irrigation applied for the various irrigation treatments (Dastane, 1978) was calculated based on the following formula for fully irrigated plants

$V_{\mathrm{id}}=\pi\left(\mathrm{D}^{2} / 4\right) \times(\mathrm{ETc}-R e) / E i$

Where, $V_{\text {id }}$ is the irrigation volume applied in each irrigation (litre plant $^{-1}$ ), D is the mean canopy spread diameter measured in northsouth and east-west direction (m), ETc, the cumulative crop evapotranspiration for two consecutive days (mm), Re the effective rainfall depth $(\mathrm{mm})$, and $E i$ the irrigation efficiency of the drip system (90\%). ETc (mm/day) was estimated as: ETc $=K_{p} \times K_{c} \mathrm{X}$ $\mathrm{E}_{\mathrm{p}}$, where, $\mathrm{K}_{\mathrm{p}}$ is the pan coefficient (0.8) and $\mathrm{Kc}$ the crop coefficient (0.85 for mature Kinnow plants) as proposed by Hasan and Sirohi (2006). The effective rainfall was estimated as the summation of change in soil water content in the root zone of the plants between, before and after rainfall, and potential evapotranspiration for 1 day (day of rainfall, mm) for the crop (Dastane, 1978).

Observation on growth parameters were taken at the beginning of trial, whereas observations on fruit characters were recorded at the time of harvesting. Tree height, stock girth and scion girth (20 cm above ground level) were recorded with measuring tape. The plant volume was calculated as per the formula given below and suggested by Westwood et al., (1963).

$\mathrm{V}=4 / 3 \pi \mathrm{a}^{2} \mathrm{~b}$

Where, 'a', represent radius of the crown of plant which was found by measuring the maximum spread in North-South and EastWest direction adding these values and dividing the sum by 4 . ' $b$ ', denotes height of the plant $(\mathrm{m})$. The length of each shoot was measured at the beginning and end of growing season between the points of initiation of new growth to the extremity of the shoot tip and expressed in centimetres. The diameter of selected fruits was measured by using a digital Vernier calliper. The fruits were weighed on electronic balance and mean weight per fruit was computed in grams. The total yield per plant was obtained through the entire crop harvested from each tree was weighed and considered as total yield and expressed in $\mathrm{kg} /$ plant. Total soluble solids (TSS) content of the juice were determined with the help of Erma-hand refractometer (0$32^{\circ}$ Brix). Titratable acidity (\%) in fresh fruits was determined by the method as suggested by AOAC (1995) and the juice per cent in 
fruits were determined according to Romero et al., (2006) method where juice of fruit was manually extracted by juice extractor and juice per cent was estimated on weight basis with respect to the fruit weight. The data was analyzed by analysis of variance (ANOVA) and $\mathrm{CD}$ was calculated at $\mathrm{P} \leq 0.05$.

\section{Results and Discussion}

\section{Plant vegetative growth}

The irrigation treatments significantly influenced the different growth parameters (plant height, stock girth, scion girth and plant volume) of plant during both the years and the trend of increase in the plant vegetative growth characteristics in relation to irrigation was similar in both years of observation however, among all the treatments the maximum plant height, stock girth, scion girth and plant volume were recorded under plants supplied with RDI at $100 \%$ ETc in early and final fruit growth period $\left(\mathrm{T}_{9}\right)$ followed by plants treated with RDI at $100 \%$ ETc at early and $50 \%$ ETc in final fruit growth period $\left(\mathrm{T}_{8}\right)$ whereas, the minimum value were with plants treated with no irrigation $\left(\mathrm{T}_{1}\right)$. The greater vegetative growth under higher irrigation regime was probably due to better leaf photosynthesis rate and higher metabolic activities of fully-irrigated plants under favourable soil water condition in the rootzone in this treatment while, the possible reason for lower growth and vigour under no irrigation or control conditions may be that the control soil moisture might have resulted into nutrient stress conditions and caused the reduction in the cell enlargement as the movement of mineral nutrient depends on mass flow of soil solution uptake, proper root respiration and diffusion by plant roots. The plants grown under rainfed conditions or water stress conditions might have might have saturated the root zone, thereby reduced the oxygen level and respiration rate resulting into low uptake of nutrients and inhibited proper growth and vigour of plants. The similar type of observations were also recorded in the earlier studies on irrigation scheduling in Nagpur mandarin (Shirgure et al., 2014), kinnow mandarin by Panigrahi et al., (2014) and Nagpur mandarin by Shirgure et al., (2016) (Table 2).

Table.1 Regulated deficit irrigation (RDI) treatments given to Kinnow mandarin

\begin{tabular}{lccc}
\hline Treatment & EFGP $(\mathbf{x})$ & MFGP $(\mathbf{y})$ & FFGP $(\mathbf{z})$ \\
\hline RDI $=0^{\mathrm{x}}-100^{\mathrm{y}}-0^{\mathrm{z}}$ & No irrigation & $100 \%$ ETc & No irrigation \\
RDI $=0^{\mathrm{x}}-100^{\mathrm{y}}-50^{\mathrm{z}}$ & No irrigation & $100 \%$ ETc & $50 \%$ Etc \\
RDI $=0^{\mathrm{x}}-100^{\mathrm{y}}-100^{\mathrm{z}}$ & No irrigation & $100 \%$ ETc & $100 \%$ ETc \\
RDI $=50^{\mathrm{x}}-100^{\mathrm{y}}-0^{\mathrm{z}}$ & $50 \%$ ETc & $100 \%$ ETc & No irrigation \\
RDI $=50^{\mathrm{x}}-100^{\mathrm{y}}-50^{\mathrm{z}}$ & $50 \%$ ETc & $100 \%$ ETc & $50 \%$ Etc \\
$\mathrm{RDI}=50^{\mathrm{x}}-100^{\mathrm{y}}-100^{\mathrm{z}}$ & $50 \%$ ETc & $100 \%$ ETc & $100 \%$ ETc \\
$\mathrm{RDI}=100^{\mathrm{x}}-100^{\mathrm{y}}-0^{\mathrm{z}}$ & $100 \%$ ETc & $100 \%$ ETc & No irrigation \\
$\mathrm{RDI}=100^{\mathrm{x}}-100^{\mathrm{y}}-50^{\mathrm{z}}$ & $100 \%$ ETc & $100 \%$ ETc & $50 \%$ Etc \\
RDI $=100^{\mathrm{x}}-100^{\mathrm{y}}-100^{\mathrm{z}}$ & $100 \%$ ETc & $100 \%$ ETc & $100 \%$ ETc \\
\hline
\end{tabular}


Table.2 Effect of regulated deficit irrigation (RDI) on vegetative growth of kinnow mandarin during 2014 and 2015

\begin{tabular}{|c|c|c|c|c|c|c|c|c|c|c|c|c|}
\hline \multirow{2}{*}{ Treatment } & \multicolumn{3}{|c|}{ Plant height (m) } & \multicolumn{3}{|c|}{ Plant volume $\left(\mathrm{m}^{3}\right)$} & \multicolumn{3}{|c|}{ Stock girth $(\mathrm{cm})$} & \multicolumn{3}{|c|}{ Scion girth $(\mathbf{c m})$} \\
\hline & 2014 & 2015 & Pooled & 2014 & 2015 & Pooled & 2014 & 2015 & Pooled & 2014 & 2015 & Pooled \\
\hline $\mathrm{T}_{1}:\left(\mathrm{RDI} 0^{\mathrm{x}}-100^{\mathrm{y}}-0^{\mathrm{z}}\right)$ & 2.36 & 2.42 & 2.39 & 10.45 & 11.02 & 10.73 & 19.00 & 27.07 & 23.04 & 16.96 & 23.95 & 20.46 \\
\hline $\mathrm{T}_{2}:\left(\right.$ RDI $\left.0^{\mathrm{x}}-100^{\mathrm{y}}-50^{\mathrm{z}}\right)$ & 2.41 & 2.49 & 2.45 & 10.97 & 11.54 & 11.26 & 20.04 & 27.97 & 24.01 & 18.05 & 25.20 & 21.63 \\
\hline $\mathrm{T}_{3}:\left(\mathrm{RDI} 0^{\mathrm{x}}-100^{\mathrm{y}}-100^{\mathrm{z}}\right)$ & 2.47 & 2.51 & 2.49 & 11.66 & 12.16 & 11.91 & 22.00 & 28.98 & 25.49 & 20.18 & 26.34 & 23.26 \\
\hline $\mathrm{T}_{4}:\left(\mathrm{RDI} 50^{\mathrm{x}}-100^{\mathrm{y}}-0^{\mathrm{z}}\right)$ & 2.54 & 2.65 & 2.60 & 12.20 & 13.06 & 12.63 & 25.10 & 30.87 & 27.99 & 23.24 & 28.58 & 25.91 \\
\hline $\mathrm{T}_{5}:\left(\mathrm{RDI} 50^{\mathrm{x}}-100^{\mathrm{y}}-50^{\mathrm{z}}\right)$ & 2.75 & 2.90 & 2.83 & 13.78 & 15.02 & 14.40 & 28.00 & 33.93 & 30.97 & 26.66 & 31.71 & 29.19 \\
\hline $\mathrm{T}_{6}:\left(\right.$ RDI $\left.50^{\mathrm{x}}-100^{\mathrm{y}}-100^{\mathrm{z}}\right)$ & 2.78 & 2.99 & 2.89 & 14.63 & 16.11 & 15.37 & 29.00 & 34.87 & 31.94 & 28.15 & 33.20 & 30.68 \\
\hline $\mathrm{T}_{7}:\left(\mathrm{RDI} 100^{\mathrm{x}}-100^{\mathrm{y}}-0^{\mathrm{z}}\right)$ & 2.63 & 2.76 & 2.70 & 12.96 & 14.06 & 13.51 & 27.20 & 32.07 & 29.64 & 25.66 & 29.97 & 27.82 \\
\hline $\mathrm{T}_{8}:\left(\right.$ RDI $\left.100^{\mathrm{x}}-100^{\mathrm{y}}-50^{\mathrm{z}}\right)$ & 2.87 & 3.11 & 2.99 & 15.70 & 17.53 & 16.62 & 29.50 & 35.73 & 32.62 & 28.64 & 34.35 & 31.50 \\
\hline $\mathrm{T}_{9}:\left(\right.$ RDI $\left.100^{\mathrm{x}}-100^{\mathrm{y}}-100^{\mathrm{z}}\right)$ & 3.02 & 3.27 & 3.15 & 16.77 & 18.85 & 17.81 & 30.30 & 36.05 & 33.18 & 29.70 & 35.00 & 32.35 \\
\hline D. $(p=0.05)$ & 0.20 & 0.53 & 0.34 & 0.51 & 0.42 & 0.46 & 0.32 & 0.26 & 0.23 & 0.44 & 0.74 & 0.54 \\
\hline
\end{tabular}

Table.3 Effect of regulated deficit irrigation (RDI) on fruit yield and quality parameters of kinnow mandarin during 2014 and 2015

\begin{tabular}{|c|c|c|c|c|c|c|c|c|c|c|c|c|}
\hline \multirow{2}{*}{ Treatment } & \multicolumn{3}{|c|}{ Fruit weight (g) } & \multicolumn{3}{|c|}{ Fruit length $(\mathrm{cm})$} & \multicolumn{3}{|c|}{ Fruit diameter $(\mathrm{cm})$} & \multicolumn{3}{|c|}{ Fruit yield $(\%)$} \\
\hline & 2014 & 2015 & Pooled & 2014 & 2015 & Pooled & 2014 & 2015 & Pooled & 2014 & 2015 & Pooled \\
\hline $\mathrm{T}_{1}:\left(\mathrm{RDI} 0^{\mathrm{x}}-100^{\mathrm{y}}-0^{\mathrm{z}}\right)$ & 114.50 & 116.00 & 115.25 & 5.39 & 5.40 & 5.40 & 6.03 & 6.04 & 6.04 & 14.87 & 15.70 & 15.29 \\
\hline $\mathrm{T}_{2}:\left(\operatorname{RDI} 0^{\mathrm{x}}-100^{\mathrm{y}}-50^{\mathrm{z}}\right)$ & 117.44 & 119.33 & 118.39 & 5.43 & 5.44 & 5.44 & 6.08 & 6.09 & 6.09 & 18.44 & 19.26 & 18.85 \\
\hline $\mathrm{T}_{4}:\left(\mathrm{RDI} 50^{\mathrm{x}}-100^{\mathrm{y}}-0^{\mathrm{z}}\right)$ & 124.62 & 126.15 & 125.39 & 5.55 & 5.56 & 5.56 & 6.19 & 6.24 & 6.22 & 27.20 & 28.02 & 27.61 \\
\hline $\mathrm{T}_{5}:\left(\mathrm{RDI} 50^{\mathrm{x}}-100^{\mathrm{y}}-50^{\mathrm{z}}\right)$ & 135.66 & 137.33 & 136.50 & 5.59 & 5.60 & 5.60 & 6.29 & 6.31 & 6.30 & 33.02 & 34.10 & 33.56 \\
\hline $\mathrm{T}_{6}:\left(\right.$ RDI $\left.50^{\mathrm{x}}-100^{\mathrm{y}}-100^{\mathrm{z}}\right)$ & 139.47 & 141.25 & 140.36 & 5.64 & 5.66 & 5.65 & 6.35 & 6.37 & 6.36 & 33.06 & 34.30 & 33.68 \\
\hline $\mathrm{T}_{8}:\left(\right.$ RDI $\left.100^{\mathrm{x}}-100^{\mathrm{y}}-50^{\mathrm{z}}\right)$ & 147.28 & 149.18 & 148.23 & 5.71 & 5.72 & 5.72 & 6.43 & 6.45 & 6.44 & 37.08 & 38.70 & 37.89 \\
\hline $\mathrm{T}_{9}:\left(\right.$ RDI $\left.100^{\mathrm{x}}-100^{\mathrm{y}}-100^{\mathrm{z}}\right)$ & 143.17 & 145.30 & 144.24 & 5.67 & 5.69 & 5.68 & 6.38 & 6.40 & 6.39 & 35.06 & 36.20 & 35.63 \\
\hline C.D. $(p=0.05)$ & 0.70 & 1.14 & 0.88 & 0.08 & 0.14 & 0.09 & 0.20 & 0.22 & 0.25 & 0.90 & 0.50 & 0.71 \\
\hline
\end{tabular}


Table.4 Effect of regulated deficit irrigation (RDI) on fruit quality of kinnow mandarin during 2014 and 2015

\begin{tabular}{|c|c|c|c|c|c|c|c|c|c|}
\hline \multirow{2}{*}{ Treatment } & \multicolumn{3}{|c|}{ Juice (\%) } & \multicolumn{3}{|c|}{ TSS $\left({ }^{0} \mathbf{B}\right)$} & \multicolumn{3}{|c|}{ Acidity (\%) } \\
\hline & 2014 & 2015 & Pooled & 2014 & 2015 & Pooled & 2014 & 2015 & Pooled \\
\hline $\mathrm{T}_{1}:\left(\right.$ RDI $\left.0^{\mathrm{x}}-100^{\mathrm{y}}-0^{\mathrm{z}}\right)$ & 46.30 & 45.22 & 45.76 & 10.60 & 10.70 & 10.65 & 0.79 & 0.78 & 0.79 \\
\hline $\mathrm{T}_{2}:\left(\mathrm{RDI} 0^{\mathrm{x}}-100^{\mathrm{y}}-50^{\mathrm{z}}\right)$ & 46.70 & 45.60 & 46.15 & 10.70 & 10.70 & 10.70 & 0.78 & 0.77 & 0.78 \\
\hline $\mathrm{T}_{3}:\left(\right.$ RDI $\left.0^{\mathrm{x}}-100^{\mathrm{y}}-100^{\mathrm{z}}\right)$ & 47.00 & 45.95 & 46.48 & 10.75 & 10.80 & 10.78 & 0.78 & 0.76 & 0.77 \\
\hline $\mathrm{T}_{4}:\left(\mathrm{RDI} 50^{\mathrm{x}}-100^{\mathrm{y}}-0^{\mathrm{z}}\right)$ & 47.20 & 46.20 & 46.70 & 10.80 & 10.85 & 10.83 & 0.77 & 0.76 & 0.77 \\
\hline $\mathrm{T}_{5}:\left(\mathrm{RDI} 50^{\mathrm{x}}-100^{\mathrm{y}}-50^{\mathrm{z}}\right)$ & 47.60 & 46.60 & 47.10 & 11.05 & 11.15 & 11.10 & 0.75 & 0.73 & 0.74 \\
\hline $\mathrm{T}_{6}:\left(\mathrm{RDI} 50^{\mathrm{x}}-100^{\mathrm{y}}-100^{\mathrm{z}}\right)$ & 48.20 & 46.85 & 47.53 & 11.10 & 11.20 & 11.15 & 0.74 & 0.72 & 0.73 \\
\hline $\mathrm{T}_{7}:\left(\right.$ RDI $\left.100^{\mathrm{x}}-100^{\mathrm{y}}-0^{\mathrm{z}}\right)$ & 47.60 & 46.53 & 47.07 & 10.85 & 10.95 & 10.90 & 0.77 & 0.75 & 0.76 \\
\hline $\mathrm{T}_{8}:\left(\right.$ RDI $\left.100^{\mathrm{x}}-100^{\mathrm{y}}-50^{\mathrm{z}}\right)$ & 48.62 & 47.05 & 47.84 & 11.30 & 11.40 & 11.35 & 0.72 & 0.70 & 0.71 \\
\hline $\mathrm{T}_{9}:\left(\mathrm{RDI} 100^{\mathrm{x}}-100^{\mathrm{y}}-100^{\mathrm{z}}\right)$ & 48.90 & 47.35 & 48.13 & 11.25 & 11.35 & 11.30 & 0.72 & 0.70 & 0.71 \\
\hline C.D. $(p=0.05)$ & 0.57 & 0.59 & 0.56 & 0.42 & 0.47 & 0.44 & 0.04 & 0.03 & 0.06 \\
\hline
\end{tabular}

Fig.1 Relation between rainfall and ETc during 2014 and 2015

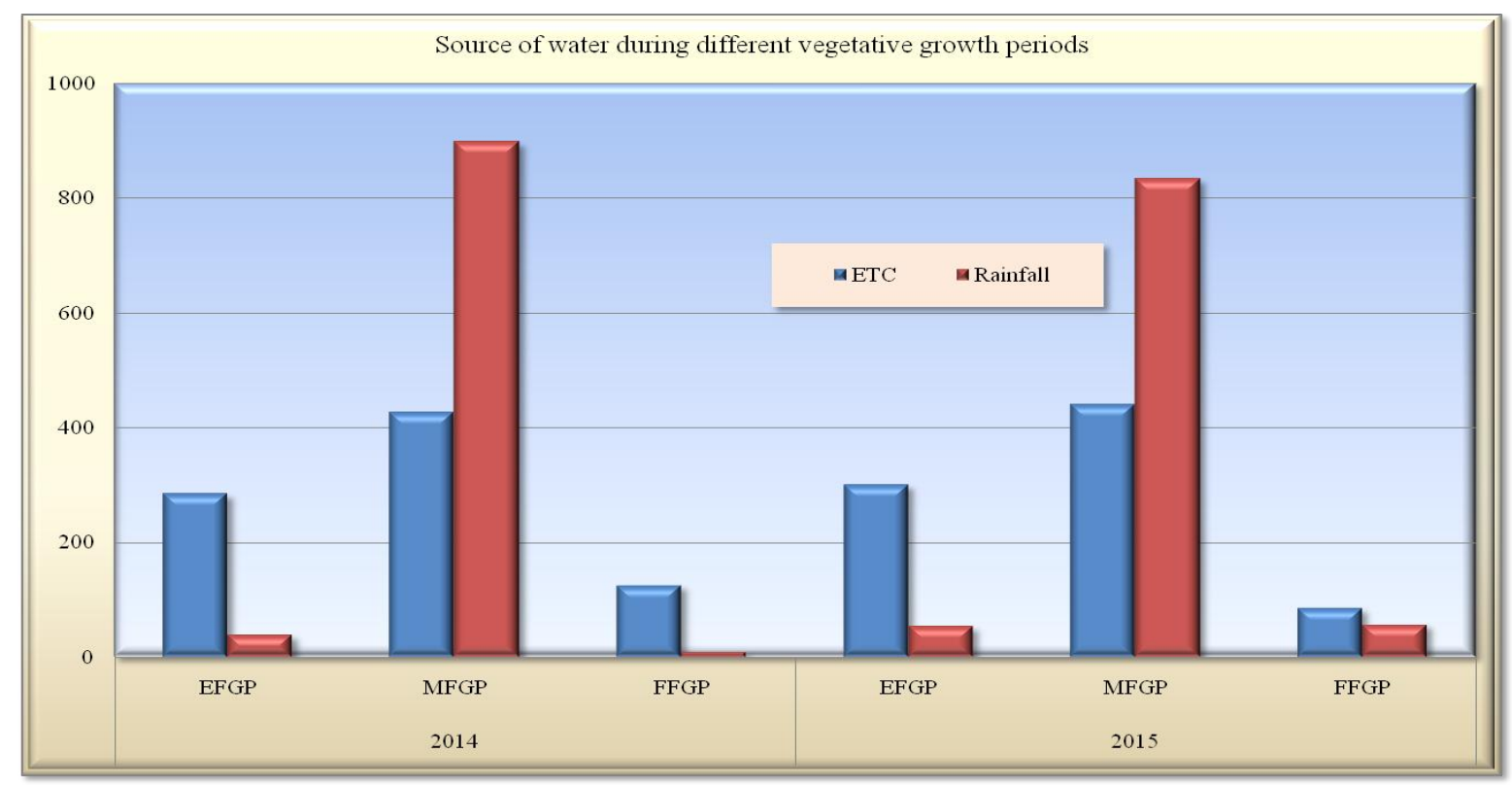




\section{Yield attributes}

Data pertaining to the yield attributes under various treatments for the two consecutive years (2013-14 and 2014-15) are presented in table 3. The fruit weight, fruit size (length and diameter) and fruit yield were recorded highest under plants receiving irrigation schedule with RDI at $100 \%$ ETc at early and $50 \%$ ETc in final fruit growth period $\left(\mathrm{T}_{8}\right)$. The possible reason for higher fruit yield under $\mathrm{T}_{8}=\mathrm{RDI}_{100-100-50}$ may be due to water deficit $(15-20 \%$ available soil water depletion) in root zone under this treatment suppressed the vegetative growth of the plants without bringing much effect on leaf photosynthesis rate and the citrus plants invested higher quantity of photosynthates towards reproductive growth (fruiting) than vegetative growth. Similarly, Proietti and Antognozzi (1990) reported that larger fruit size was primarily the result of a larger number of cells and the positive effect of water availability on the cell division rather than cell expansion. The fruit yield decreased with decreasing irrigation level from $\mathrm{T}_{8}=$ $\mathrm{RDI}_{100-100-50}$ to $\mathrm{T}_{1}=\mathrm{RDI}_{0-100-0}$, resulting from less number of fruits with lower fruit weight under lower regime of RDI. However, lowest fruit yield was recorded in unirrigated $\left(\mathrm{T}_{1}\right)$ plants. This could be caused by lower photosynthesis rate of leaves under continuous soil water deficit prevailed under control condition or probably due to reduction in availability of assimilate and lower stomatal conductance, whereas surplus water condition might have led to anaerobic conditions and reduced water and nutrient uptake, thus reduced the fruit size. These results are in association with the findings of Panigrahi et al., (2012) who observed highest yield of Nagpur mandarin under DI at $80 \%$ $\mathrm{E}_{\mathrm{cp}}$ followed by $100 \% \mathrm{E}_{\mathrm{cp}}$ whereas lowest under $40 \% \mathrm{E}_{\mathrm{cp}}$ compare to basin irrigation. The similar results of lower fruit yield with higher level of deficit irrigation were earlier reported by Garcia-Tejero et al., (2010) in Salustiana orange, Panigrahi et al., (2014) in kinnow mandarin and Shirgure et al., (2014) in Nagpur mandarin.

\section{Fruit quality}

The effect of irrigation on fruit quality parameters (Total soluble solid content, Acidity, Juice content) is presented in table 4. Juice per cent increased from $\operatorname{RDI}_{0-100-0}\left(\mathrm{~T}_{1}\right)$ to $\mathrm{RDI}_{100-100-100}\left(\mathrm{~T}_{9}\right)$, indicating the excess dehydration of juice sacs of fruits with no irrigation $\left(\mathrm{RDI}_{0-100-0}\right)$, which could not be fulfilled by osmotic adjustment to maintain sufficient turgidity of fruits in this treatment. The TSS increased from $\mathrm{RDI}_{0-100-0}$ to $\mathrm{RDI}_{100}$ 100-50 and then decreased at RDI $100-100-100$ (Full irrigated). The higher juice content is one of the reasons for dilution of soluble solids concentrations in fruits with full irrigated. Moreover, the acidity percentage in juice was recorded maximum with $\mathrm{RDI}_{0-100-0}$. The higher acidity and lower total soluble solid with the fruits in $\mathrm{RDI}_{0-100-0}$ treatment compared to other treatments was probably caused by enhanced transformation of acids to sugars in dehydrated juice sacs which is required to maintain the osmotic pressure of fruit cells under mild water deficit condition (Huang et al., 2000). Earlier studies also demonstrated the greater TSS in citrus fruits under soil water deficit condition in root zone of plants (Navarro et al., 2010) and Panigrahi et al., (2014) in kinnow mandarin.

In conclusion, the fully-irrigated 'Kinnow' mandarin plants produced the highest vegetative growth while, maximum fruit yield with better quality was recorded under plant treated with RDI at $100 \%$ ETc at early and $50 \%$ ETc in final fruit growth period $\left(\mathrm{T}_{8}\right)$. However, deficit irrigation scheduled at 50\% crop evapotranspiration at final fruit growth period improved fruit quality with higher total soluble solid and lower acidity. Moreover, 
better quality citrus fruits were harvested from the deficit-irrigated plants in both the years of study. Based on these results, it can be inferred that application of irrigation water at $50 \%$ crop evapotranspiration at final fruit growth period could be a better option for 'Kinnow' mandarin cultivation in water scarce areas of northern India and elsewhere having similar agro-climatic condition.

\section{References}

A.O.A.C. 1995. Official methods of analysis of $16^{\text {th }}$ edition. Association of Analytical Chemists, Washington, D.C.

Abu-Awwad, A. M., 2001. Influence of different water quantities and qualities on lemon trees and soil salt distribution at the Jordan Valley. Agric Water Manag, 52: 53-71.

Bhat, A., Kachroo, J. and Kachroo, D. 2011. Economic appraisal of kinnow production and its marketing under north-western Himalayan region of Jammu. Agric. Econ. Res. Rev., 24: 283290.

Dastane, N. G., 1978. Effective rainfall in irrigated agriculture. FAO Irrigation and Drainage Paper 25, FAO, Rome, Italy.

Dhillon, B.S. 1986. Bio-regulation of developmental process and subsequent handling of Kinnow mandarin. Acta Hortic., 179:251-256.

Garcia-Tejero, I., Jimenez-Bocanegra, J. A., Martinez, G., Romero, R., DuranZuazo, V. H. and Muriel-Fernandez, J. L. 2010. Positive impact of regulated deficit irrigation on yield and fruit quality in a commercial citrus orchard (Citrus sinensis (L.) Osbeck, cv. salustiano). Agric. Water Manag, 97: 614-622.

Goldhamer, D. A. A. 2003. Regulated deficit irrigation of trees and vines in agricultural water management. In: Holiday, L. (Eds.). Proceedings of a workshop in Tunisia (Series: Strengthening science-based decision making in developing countries), pp 7080. National Research Council of the National Acadamies, Washington.

Hasan, M. and Sirohi, N. P. S. 2006. Irrigation and fertigation scheduling for peach and citrus crops. J. Agri. Eng., 43(4): 43-46.

Huang, X. M., Huang, H. B. and Gao, F. F. 2000. The growth potential in citrus fruit under water stress and its relevant mechanisms. Sci. Hortic., 83: 227-240.

Kallsen, C.E. and B. Sanden. 2011. Early Navel orange fruit yield, quality, and maturity in response to late-season water stress. Hortic. Sci., 46: 11631169.

Navarro, J. M., Perez-Perez, J. G., Romero, P. and Botía, P. 2010. Analysis of the changes in quality in mandarin fruit, produced by deficit irrigation treatments. Food Chem., 119: 15911596.

Panigrahi, P. and Srivastava, A.K. 2011. Deficit irrigation (DI) scheduling for matured Nagpur mandarin (Citrus reticulata Blanco) trees of central India. Indian J. Soil Conserv, 39(2): 149-154.

Panigrahi, P., Srivastava, A. K. and Huchche, A. D. 2012. Effects of drip irrigation regimes and basin irrigation on Nagpur mandarin agronomical and physiological performance. Agr. Water Manage, 104: 79-88

Panigrahi, P., Sharma, R. K. Hasan, M. and Parihar, S. S. 2014. Deficit irrigation scheduling and yield prediction of Kinnow mandarin (Citrus reticulate Blanco) in a semiarid region. Agr. Water Manage, 140: 48-60.

Proietti, P. and Antognozzi, E. 1996. Effect of irrigation on fruit quality of table olives (Olea europaea), cultivar 'Ascolana tenera'. N. Z. J. Crop Hortic. Sci., 24: 175-181. 
Romero, P., Navarro, J. M., Perez-Perez, J., Garcia-Sanchez, F., Gomez-Gomez, A., Porras, I., Martinez, V. and Botía, P. 2006. Deficit irrigation and rootstock: their effects on water relations, vegetative development, yield, fruit quality and mineral nutrition of Clemenules mandarin. Tree Physiol., 26: 1537-1548.

Shirgure, P. S., Srivastava, A. K. and Huchche, A. D. 2014. Water requirements in growth stages and effects of deficit irrigation on fruit productivity of drip irrigated Nagpur mandarin (Citrus reticulata). Indian J. Agr. Sci., 84(3): 317-322
Shirgure, P. S., Srivastava, A. K. and Huchche, A. D. 2016. Effect of drip irrigation scheduling on yield and quality of Nagpur mandarin (Citrus reticulata Blanco) fruits. Indian $J$. Hort., 73(1): 30-35

Singh, S. and Srivastava, A. K. 2004. Citrus industry of Indian and overseas. In: Singh, S. Shivankar, V. J., Srivastava, A. K. and Singh, I. P. (Eds). Advances in Citriculture, Jagmander Book Agency: New Delhi; 8-67.

Westwood, M. N. 1978.Temperate Zone Pomology, W. H. Freeman Co. San Francisco California, pp. 223-428.

\section{How to cite this article:}

Disket Dolker, Parshant Bakshi, Stanzin Dorjey, Preeti Choudhary, Kiran Kour and Mahender Singh. 2017. Effect of Deficit Irrigation Scheduling on Yield and Quality of Kinnow Mandarin Fruits. Int.J.Curr.Microbiol.App.Sci. 6(7): 261-269. doi: https://doi.org/10.20546/ijcmas.2017.607.031 